Relations industrielles

Industrial Relations

\title{
Nan Weiner and Morley Gunderson, Pay Equity, Issues, Options and Experiences
}

\section{Esther Déom}

Volume 46, numéro 2, 1991

URI : https://id.erudit.org/iderudit/050681ar

DOI : https://doi.org/10.7202/050681ar

Aller au sommaire du numéro

Éditeur(s)

Département des relations industrielles de l'Université Laval

ISSN

0034-379X (imprimé)

1703-8138 (numérique)

Découvrir la revue

Citer ce compte rendu

Déom, E. (1991). Compte rendu de [Nan Weiner and Morley Gunderson, Pay Equity, Issues, Options and Experiences]. Relations industrielles / Industrial Relations, 46(2), 477-478. https://doi.org/10.7202/050681ar

Tous droits réservés @ C Département des relations industrielles de l'Universite Laval, 1991
Ce document est protégé par la loi sur le droit d'auteur. L’utilisation des services d'Érudit (y compris la reproduction) est assujettie à sa politique d'utilisation que vous pouvez consulter en ligne.

https://apropos.erudit.org/fr/usagers/politique-dutilisation/ 


\section{RECENSIONS} BOOK REVIEWS

Pay Equity. Issues, Options and Experiences, par Nan Weiner et Morley Gunderson, Toronto et Vancouver, Butterworths, 1990. 171 p., ISBN 0-409-89772-8.

Depuis quelque temps, les publications de toutes sortes sur le sujet de l'équité salariale foisonnent. La diversité et la multiplicité des expériences d'implantation de programmes d'équité salariale maintenant en cours permettent dorénavant de dépasser le niveau des seules discussions théoriques pour envisager les problèmes techniques découlant de l'implantation du principe dans les entreprises. Les auteur-e-s du présent volume ont ainsi pu puiser dans les nombreuses expériences vécues dans les secteurs public et privé ontariens, leur province d'origine, pour of frir aux personnes intéressées par le sujet un volume pratique qui présente les principales étapes d'implantation d'un programme d'équité salariale.

Dans cet esprit, les nombreux concepts (écart salarial, prédominance sexuelle des emplois, sous-évaluation des emplois «féminins", etc.) qui permettent de comprendre la problématique de l'équité salariale sont présentés d'une manière très générale. Le coeur du volume vise en effet à préciser les particularités d'une démarche d'évaluation des emplois entreprise dans le cadre d'un programme d'équité salariale par rapport à une démarche «traditionnelle» qui se déroule en marge de ces préoccupations.

Le chapitre 4 identifie ainsi les étapes à surveiller et les moyens de minimiser les biais sexistes dans le processus d'évaluation: lors de la cueillette des renseignements, dans le choix et la définition des facteurs d'évaluations, dans la pondération des facteurs et sous-facteurs, dans la sélection et la formation du comité d'évaluation et dans l'évaluation elle-même.

Le chapitre 5 suggère plus précisément certains moyens pour éviter les biais sexistes dans l'utilisation de l'une ou l'autre des différentes méthodes traditionnelles d'évaluation (rangement, classification, par facteur et par points) et présente certaines adaptations de ces méthodes, élaborées spécifiquement pour réaliser l'équité salariale (comparaison par paires de facteurs, technique du policy capturing). Ce chapitre fournit aussi quelques conseils utiles pour choisir un-e consultant-e en équité.

Le chapitre 6 présente les avantages et inconvénients, du point de vue de l'équité salariale, des différentes méthodes de correction des écarts sexistes identifiés suite à l'évaluation des emplois: l'approche courbe salariale à courbe salariale, l'approche emploi à emploi, l'approche emploi à courbe salariale et celle de l'écart décroissant.

Le chapitre 7 traite brièvement de rôle de la négociation collective et du syndicat et des effets potentiels d'un programme d'équité salariale sur le processus de négociation collective. Les deux chapitres suivants présentent la législation actuellement en vigueur et des expériences vécues au Canada (chap. 8) et dans certains autres pays (chap. 9). Enfin, le dernier chapitre conclut sur les effets potentiels de l'équité salariale sur les organisations.

La facture générale du livre plaira certainement aux intervenant-e-s qui auront à implanter des programmes d'équité salariale. C'est en effet un volume qui s'adresse particulièrement aux praticien-nes. Étant donnée le public visé, on peut ainsi dire que le livre va droit au but (i.e. les 
questions techniques liées à l'implantation d'un programme d'équité salariale) sans s'embarasser de considérations théoriques. On remarque cependant certaines lacunes: une présentation non uniforme des différentes méthodes d'évaluation, un traitement assez général de l'étape d'évaluation elle-même, la mise de côté de certaines approches de correction des écarts salariaux et la quasi-absence de considérations sur la situation d'entreprises qui voudraient entreprendre des comparaisons d'emplois entre des familles différentes (comparaisons interfamilles) qui peuvent être syndiquées et à des syndicats différents. En effet, les discussions portent presqu'uniquement sur les comparaisons intra-familles, base de la législation ontarienne, par ailleurs fort critiquée car on sait que les écarts inter-familles contribuent pour beaucoup au maintien des écarts discriminatoires de salaires.

Il est aussi dommage que les auteur-e-s n'aient pas toujours su présenter les impacts importants de certaines décisions techniques (choix du seuil de prédominance par exemple) sur le type d'équité salariale qui sera réalisé. Enfin, les auteur-es insistent très peu sur les différences qui existent entre une démarche ad hoc de correction des écarts sexistes (utilisation ponctuelle d'un processus non-sexiste incluant le plan d'évaluation) et une démarche intégrée d'équité salariale (changement permanent du processus d'évaluation).

Comme ce livre «colle» plus spécifiquement à la situation de l'Ontario, il sera surtout utile aux praticien-nes de cette province ou d'autres provinces qui devront sous peu préparer et afficher des programmes d'équité salariale selon le modèle mis en place par la législation ontarienne.

Esther Déom

Université Laval

The Economics of Comparable Worth, by Mark R. KiLLINGSworth, Kalamazoo, Michigan, W.E. Upjohn Institute for Employment Research, 1990, 225 p. ISBN 0-88099-086-4 ISBN 0-88099-085-6 (pbk.).

The issue of comparable worth/equal value has evoked considerable debate in the U.S. and Canada in recent years. The primary objective of the present book is to contribute to the two areas in which the author claims this debate "has been sadly deficient". "First, in much of the controversy, both proponents and opponents have failed to define terms and concepts clearly - even the concept of comparable worth itself. Relatively little effort has been devoted to describing, in concrete terms, what would be involved in implementing and enforcing a policy of equal pay for jobs of comparable worth. [...] A second problem with public debate on comparable worth is that protagonists have often been preoccupied with essentially ideological and normative issues to the almost total exclusion of important conceptual and empirical questions. [...] Both sides in the debate seem to agree that comparable worth is intended to serve as a means of readressing some of the economic effects of discrimination against (or labor market segmentation of) women. The likely effects, however, of actual or potential comparable worth policies on labor market outcomes for women - on wages, employment, etc. have received relatively little attention."'

Excluding the introductory chapter, the book consists of six chapters. Chapters 2 and 3 are devoted to a theoretical treatment of various definitional, analytical and methodological issues concerning comparable worth. Next three chapters provide detailed case studies of three jurisdictions (Minnesota, and San José in the U.S. and Australia) which have already implemented comparable worth policies. In the final chapter, the author draws some conclusions from his analyses in the preceding chapters and offers, very briefly, two alternatives to comparable worth policies. 